\title{
ОСОБЛИВОСТІ ВИМІРЮВАННЯ ТЕМПЕРАТУРИ ЦИЛІНДРИЧНИХ ОБЕРТОВИХ ПОВЕРХОНЬ
}

Розглянуто методи вимірювання температури циліндричних обертових поверхонь на основі контактного вимірювання температури пристінного шару робочого середовища, що омиває обертову поверхню, яка має функціональну залежність 3 температурою поверхні. Показано, що пристінний шар робочого середовища між обертовою поверхнею і перетворювачем має деякий перепад температур, що $є$ основним джерелом виникнення методичної похибки вимірювання температури обертової поверхні. Розроблено методику математичного опису теплових процесів, що відбуваються під час вимірювання температури циліндричних обертових поверхонь, та узагальнено стаціонарну математичну модель процесу вимірювання температури обертових поверхонь, яка характеризує зв'язок між вхідними, вихідними, керуючими і збурювальними параметрами процесів передачі тепла під час вимірювання температури обертових поверхонь у стаціонарному режимі. Аналіз розробленої математичної моделі дав змогу зменшити тепловтрати через перетворювачі та синтезувати перетворювачі температури 3 мінімальним значенням методичної похибки вимірювання температури для заданих умов експлуатації. Розглянуто особливості метрологічної перевірки перетворювачів температури та запропоновано установку для іiї проведення, що дало змогу спростити метрологічну перевірку і підвищити її точність.

Ключові слова: вимірювання температури; обертові циліндричні поверхні; перетворювач температури; тепловий потік; математична модель; методична похибка; метрологічна перевірка.

Вступ. У сучасних процесах виробництва тонких органічних пластиків, шинного корда, паперу, прокату чорних і кольорових металів застосовують обладнання з гладкими обертовими циліндричними валками і барабанами. Температура поверхні цих об'єктів є важливим параметром технологічного процесу, визначає кількісні та якісні показники вихідного продукту, наявність браку, а також стан технологічного обладнання. Тому вимірювання температури таких поверхонь потрібно проводити неперервно 3 високою точністю і невеликою інерційністю. Існують різні методи вимірювання таких температур: за температурою і кількістю теплоносія або холодоагента, що застосовують для забезпечення температурного режиму; метод плавких вставок і термоіндикаторів; методи, що потребують прямої видимості місць вимірювання або теплового контакту; методи, засновані на випроміненні поверхні та ін.

Зазначені методи дають змогу отримати одноразову дискретну інформації, яка характеризує тільки загальний тепловий стан обертової поверхні, є найменш універсальною і застосовуються іiі тільки в лабораторній або дослідницькій практиці.

Найбільш ефективними для неперервного вимірю- вання температури є методи електротермометрії, які дають змогу проводити вимірювання і мають такі переваги: високу чутливість і можливість їі зміни в широкому діапазоні значень вимірюваної температури; незначну інерційність електричної апаратури; можливість дистанційного вимірювання; математичну обробку і можливість застосування в системах контролю і регулювання. Тому розроблення перетворювачів для вимірювання температури циліндричних обертових поверхонь із використанням методів електротермометрії є доцільним.

Аналіз літературних джерел. Вимірювання температури циліндричних обертових поверхонь (ОП) методами електротермометрії розглянуто в деякій кількості робіт, запропоновано певні конструктивні рішення, але практично відсутні перетворювачі, які здатні надійно працювати в промислових системах автоматичного контролю і керування (Vankevych et al., 2017; Stepaniak et al., 2010; Vankevych, 2017; Ilkiv et al., 2010). Це пояснюють тим, що такі прилади експлуатуються у складних умовах, піддаються багатофакторним впливам як зі сторони досліджуваної ОП (температура, механічні та вібраційні навантаження, стан поверхні, лінійна швидкість руху), так і зі сторони навколишнього середовища

\section{Інформація про авторів:}

Фединець Василь Олексійович, д-р техн. наук, доцент, кафедра автоматизації та комп'ютерно-інтегрованих технологій.

Email: v.fedynets@ukr.net; https://orcid.org/0000-0002-9392-7491

Юсик Ярослав Петрович, канд. техн. наук, доцент, кафедра автоматизації та комп'ютерно-інтегрованих технологій.

Email: yusik@ukr.net; https://orcid.org/0000-0001-5495-5206

Васильківський Ігор Степанович, канд. техн. наук, доцент, кафедра автоматизації та комп'ютерно-інтегрованих технологій. Email: vis@ukr.net; https://orcid.org/0000-0001-9172-4765

Цитування за ДСтУ: Фединець В. О., Юсик Я. П., Васильківський І. С. Особливості вимірювання температури циліндричних обертових поверхонь. Науковий вісник НЛтУ України. 2018, т. 28, № 11. С. 78-84.

Citation APA: Fedynets, V. O., Yusyk, Ya. P., \& Vasylkivskyi, I. S. (2018). Some features of measuring the temperature of cylindrical rotating surfaces. Scientific Bulletin of UNFU, 28(11), 78-84. https://doi.org/10.15421/40281115 
(температура, агрегатний стан, зміна теплофізичних властивостей).

Принципові рішення для вимірювання температури ОП методами електротермометрії зводяться до двох основних методів: безконтактного (Petrychenko et al., 2011; Lutsyk et al., 2006) і контактного (Vankevych et al., 2017; Ilkiv et al., 2010; Lutsyk et al., 2006). Безконтактні методи засновано на принципі застосування енергії теплового випромінення (пірометри) і їхньою перевагою $є$ те, що вони не втручаються в межі зони вимірювання, забезпечують високу роздільну здатність у часі та просторі. Однак під час застосування пірометрів треба враховувати, що приведений коефіцієнт теплового випромінення досліджуваної поверхні не перевищує значень $0,1 \ldots 0,4$ і може змінюватися у процесі експлуатації. А це буде призводити до спотворення результатів вимірювання і неможливості правильного представлення про дійсну температуру досліджуваної поверхні. Тому прилади на основі безконтактних методів застосовують тільки для отримання одноразової дискретної інформації про температуру обертової поверхні.

Вимірювання температури контактними методами має три різновиди. У першому випадку перетворювач закріплюється нерухомо на ОП у паз, розміщений вздовж ізотермічної поверхні (Vankevych, 2016). Головна складність у цьому випадку виникає у разі забезпечення надійної передачі вимірювальної інформації від розміщеного на ОП перетворювача до вимірювальної апаратури, розміщеної нерухомо. Передача вимірювальної інформації може здійснюватися дротовим і бездротовим зв'язком. Для бездротового зв'язку застосовують модуляційні радіочастотні та телеметричні приймачі-передавачі. Проте через складність схемних рішень і високої вартості вони не набули значного поширення і застосовуються дуже рідко й тільки в дослідницькій практиці. Для дротового зв'язку необхідно застосовувати струмознімальні пристрої, які складаються із пари "кільце - щітка". Основними завадами в струмознімальних пристроях є перехідні опори і контактні термоелектрорушійні сили. Миттєві значення цих параметрів $\epsilon$ кривими, які нестійкі в часі, мають піковий характер аж до повних розривів електричного кола, а їхні середні значення дуже чутливі до умов зовнішнього середовища і режиму роботи ОП. Окрім цього, розміщення перетворювача в пазі на ОП призводить до спотворення температурного поля, яке виникає внаслідок контакту ОП із перетворювачем. Внаслідок цього виникає додаткова похибка, зумовлена недосконалістю теплового контакту, відмінностями коефіцієнтів теплопровідності ОП і перетворювачами та іншими чинниками. Через наведені вище недоліки, а також через те, що на більшості ОП із технологічних міркувань не допускається наявність пазів чи виступаючих елементів цей метод не набув значного промислового впровадження.

Інша різновидність контактного методу полягає в тому, що перетворювач закріплюється нерухомо відносно ОП, а його чутливий елемент знаходиться в безпосередньому механічному контакті з ОП (Vankevych et al., 2017; Ilkiv et al., 2010). Результати вимірювання температури такими перетворювачами дуже спотворюються похибками від тертя, які залежать від лінійної швидкості, коефіцієнта тертя матеріалу ОП і чутливого елемента, а також від зусилля притиску. Окрім цього, через зміни зусилля притиску і лінійної швидкості в про- цесі експлуатації ОП ця похибка часто стає невизначеною. Тому такі перетворювачі через значну і нестабільну похибки від тертя, а також зносу чутливого елемента внаслідок тертя і відповідно обмеженого терміну служби, не можна застосовувати для надійної і тривалої роботи в системах автоматичного контролю температури ОП.

У третьому різновиді контактного методу перетворювач також закріплюється нерухомо відносно ОП, але на деякій віддалі (до 2 мм) і вимірює температуру пристінного шару робочого середовища, яка має функціональну залежність 3 температурою ОП (Vankevych, 2017; Lisienko et al., 2004). Внаслідок цього виключається похибка від тертя, зношування перетворювача, збільшується термін служби, надійність і вірогідність отримання правильної вимірювальної інформації про температуру ОП. Однак пристінний шар робочого середовища між ОП і перетворювачем має деякий перепад температур, у ньому відбуваються теплові втрати через теплопровідність у робочому зазорі, конвекцію і випромінення, що $\epsilon$ основним джерелом виникнення методичної похибки вимірювання температури ОП. Тому виникає необхідність розроблення методів зменшення тепловтрат і відповідно методичної похибки вимірювання. Дослідження цих питань розглядаємо в цій роботі.

Метою дослідження є розроблення математичного опису теплових процесів, що відбуваються під час вимірювання температури циліндричних ОП та його застосування для побудови математичної моделі, яка дасть змогу синтезувати конструкцію вимірювального блоку перетворювача 3 мінімальною методичною похибкою вимірювання температури.

Для досягнення поставленої мети в роботі необхідно вирішити такі завдання:

- розробити методику математичного опису теплових процесів із застосуванням інструментарію теорії теплопередачі;

- розробити узагальнену математичну модель для аналізу зв'язків між вхідними і вихідними параметрами процесу вимірювання;

• на основі аналізу математичної моделі розробити конструкторські рішення для зменшення теплових втрат через перетворювач і зменшення методичної похибки вимірювання;

- розробити методологію метрологічної перевірки перетворювачів на основі результатів досліджень та застосувати їх для побудови спрощеної конструкції перевірювальної установки.

Викладення основного матеріалу. Як зазначали вище, перетворювачі експлуатуються у складних умовах, піддаються різним тепловим впливам як зі сторони досліджуваної поверхні, так і з навколишнім середовищем. Тому ці умови зумовлюють труднощі розроблення і створення надійних перетворювачів для вимірювання температури ОП.

Основними тепловими впливами є (рис. 1):

- тепловий потік від досліджуваної поверхні через робочий зазор до перетворювача $Q_{n}$;

- тепловий потік теплопровідністю через перетворювач у навколишнє середовище $Q_{1}$;

- теплообмін природною конвекцією між зовнішньою $Q_{2}$ i боковими $Q_{3}$ поверхнями захисного корпусу і навколишнім середовищем;

- теплообмін випроміненням між захисним корпусом перетворювача і навколишнім середовищем $Q_{4}$.

Передача тепла $Q_{n}$ від досліджуваної поверхні до перетворювача здійснюється через робочий зазор $\delta$ через 
теплопровідність робочого середовища в зазорі, випроміненням поверхні, а також конвекцією, викликаною штучним перемішуванням робочого середовища в зазоpi за рахунок обертання поверхні. Передача тепла від перетворювача в навколишнє середовище здійснюється через теплопровідність (тепловий потік $Q_{1}$ ) у напрямку, перпендикулярному до площини теплоприймальної поверхні перетворювача, природною конвекцією від зовнішньої $\left(Q_{2}\right)$ і бокових $\left(Q_{3}\right)$ тепловіддаючих поверхонь, а також випроміненням $\left(Q_{4}\right)$ від зазначених поверхонь.

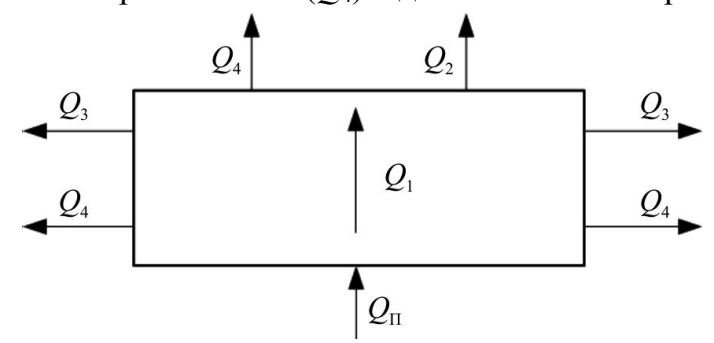

Рис. 1. Основні теплові впливи на термоперетворювач

Систему "досліджувана обертова поверхня - робочий зазор - модель перетворювача" зображено на рис. 2. Геометрична модель перетворювача представляє собою напівциліндричне тіло радіусом $r$, довжиною $l$, яке встановлено з фіксованим зазором $\delta$ від поверхні. Значення робочого зазору $є$ однаковим по всій теплоприймальній поверхні моделі перетворювача. Температура поверхні приймається рівною $t_{n}$, лінійна швидкість руху поверхні становить $V$. Температура чутливого елемента перетворювача te є постійною по всій його довжині та меншою від температури поверхні $(t e<t n)$, фізичні властивості робочого середовища в зазорі за температури $t$ приймаються постійними.

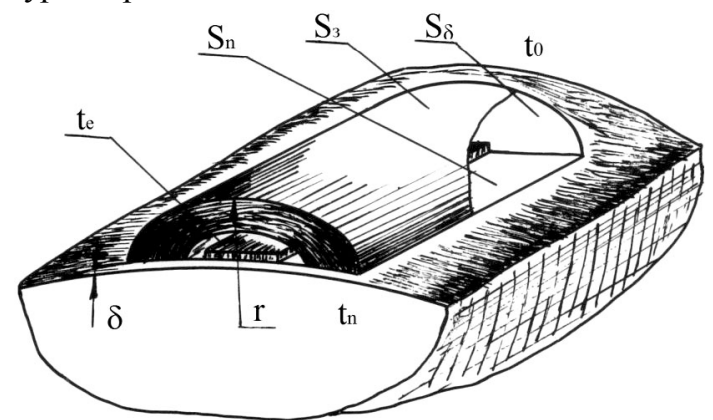

Рис. 2. Система "досліджувана обертова поверхня - робочий зазор - модель перетворювача"

Технологічні процеси, що протікають на обертових поверхнях, зазвичай $є$ стаціонарними, тому розглянемо стаціонарну математичну модель процесу вимірювання температури за допомогою перетворювачів, заснованих на контактному вимірюванні температури пристінного шару робочого середовища, що омиває валок. Для таких моделей математичний опис визначають значеннями параметрів моделі, що відповідають стаціонарному стану об'єкта дослідження за заданої сукупності параметрів. Побудову математичної моделі починаємо 3 формалізованого опису об'єкта моделювання, який є сукупністю залежностей, що пов'язують всі параметри в єдину систему рівнянь.

Вхідними параметрами моделі, які можна виміряти, але не можна впливати на них, є температура досліджуваної поверхні $t_{n}$, значення робочого зазору $\delta$ і лінійна швидкість обертання поверхні $V$. До керуючих параметрів, на які можна впливати відповідно до тих чи інших вимог, належать геометричні параметри: $r$ - радіус; $l$ довжина перетворювача. Збурювальними параметрами, значення яких випадково змінюються у часі та які недоступні для вимірювання, $є$ зміни температури і теплофізичних властивостей навколишнього середовища, лінійної швидкості поверхні та робочого зазору. Вихідним параметром $\epsilon$ температура чутливого елемента $t_{e}$ (покази приладу).

Стаціонарний процес вимірювання температури 3 вхідними, вихідними, керуючими та збурювальними параметрами представлено на рис. 3 на основі закону збереження енергії

$$
Q_{n}-Q_{1}-Q_{2}-Q_{3}-Q_{4} .
$$

Застосовуючи для теплових потоків відомі закономірності (Isachenko et al., 1981; Mikheev \& Mikheeva, 1977; Kutateladze, 1990), отримаємо математичний опис теплових процесів, що відбуваються під час вимірювання температури обертових поверхонь у стаціонарному режимі:

$$
\begin{gathered}
S_{n}\left\langle\left(\frac{\lambda}{\delta}+\alpha\right)\left(t_{n}-t_{e}\right)+C_{n}\left[\left(\frac{T_{n}}{100}\right)^{4}-\left(\frac{T_{e}}{100}\right)^{4}\right]\right)-k l\left(t_{e}-t_{k}\right)- \\
\alpha_{3} S_{3}\left(t_{k}-t_{0}\right)-\alpha_{6} S_{6}\left(t_{k}-t_{0}\right)-C_{3}\left(S_{3}+S_{6}\right)\left[\left(\frac{T_{k}}{100}\right)^{4}-\left(\frac{T_{0}}{100}\right)^{4}\right]=0,
\end{gathered}
$$

де: $S_{n}, S_{3}, S_{6}-$ відповідно площі теплоприймальної поверхні, зовнішньої і бокової поверхонь перетворювача; $\delta$ - величина робочого зазору між досліджуваною поверхнею і перетворювачем; $\lambda$ - коефіцієнт теплопровідності середовища в робочому зазорі; $\alpha, \alpha_{3}, \alpha_{\sigma}-$ відповідно коефіцієнти конвективної тепловіддачі в робочому зазорі, зовнішньої і бокової поверхонь перетворювача; $k$ - коефіцієнт теплопередачі через перетворювач; $C_{n}$, $C_{3}-$ відповідно наведений коефіцієнт теплового випромінення досліджуваної поверхні і захисного корпусу перетворювача; $t_{n}, t_{e}, t_{k}, t_{0}$ - відповідно температури поверхні, чутливого елемента та захисного корпусу перетворювача і навколишнього середовища; $T_{n}, T_{e}, T_{k}, T_{0}-$ відповідно термодинамічні значення цих температур.

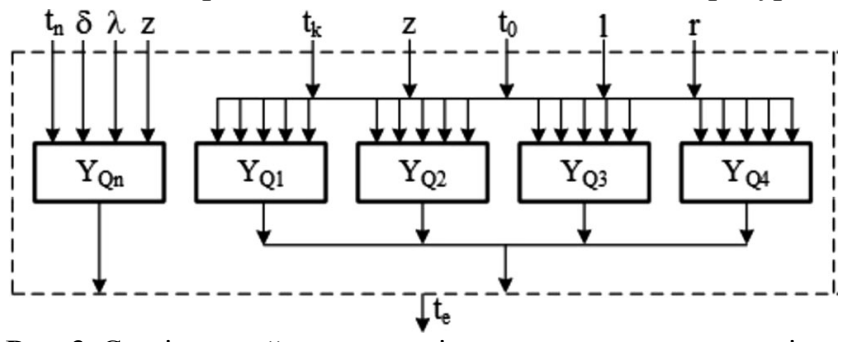

Рис. 3. Стаціонарний процес вимірювання температури з вхідними, вихідними, керуючими та збурювальними параметрами

Для вивчення властивостей об'єкта моделювання за його математичним описом необхідно розв'язати рівняння (2) відносно деякого параметра, чим власне i здійснюється процес математичного моделювання. Найбільший інтерес становить визначення із рівняння величини $\Delta t=t_{e}-t_{n}-$ методичної похибки перетворювача, яка характеризує зв'язок між вхідними і вихідними параметрами залежно від впливу керуючих і збурювальних параметрів. Враховуючи відомі залежності для коефіцієнтів тепловіддачі $\alpha_{3}$ і $\alpha_{5}$ та коефіцієнта теплопередачі $k$ (Isachenko et al., 1981; Mikheev \& Mikheeva, 1977; Kutateladze, 1990), перетворювача рівняння (2) набуде вигляду: 


$$
\Delta t=-\frac{k l\left(t_{e}-t_{k}\right)+\alpha_{3} S_{3}\left(t_{k}-t_{0}\right)+\alpha_{6} S_{\sigma}\left(t_{k}-t_{0}\right)+C_{3}\left(S_{3}+S_{\sigma}\right) \Delta T}{S_{n}\left[\left(\frac{\lambda}{\delta}+\alpha\right)+0,04 C_{n}\left(\frac{T_{e}}{100}\right)^{3}\right]},
$$

де $\Delta T=\left(\frac{T_{k}}{100}\right)^{4}-\left(\frac{T_{0}}{100}\right)^{4}$.

Цей вираз $є$ в загальному вигляді стаціонарною детермінованою математичною моделлю процесу вимірювання температури обертових поверхонь.

Тепловий потік $Q_{n}$ від досліджуваної поверхні до перетворювача $\epsilon$ корисним (інформативним) параметром вхідного сигналу. Решта теплових впливів призводять до виникнення неінформативного параметра вхідного сигналу і до відхилення показів перетворювача від температури досліджуваної поверхні, що є джерелом виникнення методичної похибки вимірювання. Тому необхідно знайти такі керуючі впливи, зміною яких можна буде регулювати методичну похибку вимірювання. Такими керуючими параметрами $є$ геометричні розміри перетворювача $r$ і $l$, через які визначаються всі коефіцієнти конвективної тепловіддачі та відповідно всі теплові потоки. 3 огляду на те, що одночасно складно варіювати зміною двох геометричних параметрів, та в цьому і немає необхідності, як незалежний керуючий параметр приймаємо радіус $r$ перетворювача, а довжину $l$ будемо задавати дискретними значеннями, виходячи 3 необхідності отримання певних геометричних співвідношень, естетичних та ергономічних вимог. Вибір оптимального значення керуючого параметра $r$ дасть змогу мінімізувати значення методичної похибки вимірювання для конкретного конструктивного виконання перетворювача завдяки досягненню оптимальних значень коефіцієнтів конвективної тепловіддачі $\alpha_{3}$ i $\alpha_{\sigma}$. Абсолютний же рівень значення похибки буде залежати від коефіцієнта теплопередачі через перетворювач $k$ i коефіцієнта конвективної тепловіддачі в робочому зазоpi $\alpha$, тобто від конструктивно вибраних методів зменшення тепловтрат.

Найбільш відомими методами зменшення тепловтрат $є$ застосування принципу неперервної циркуляції робочого середовища пристінного шару навколо чутливого елемента перетворювача відповідно до закону Бернуллі - Сен-Венана, що виникає завдяки руху поверхні, та застосування теплових екранів (Lebed et al., 2011; Ivanyk et al., 2015).

Під час застосування принципу неперервної циркуляції в конструкції перетворювача зі сторони чутливого елемента передбачено дві щілини різної площі, що з'єднуються між собою кільцевим каналом. За рахунок різної площі щілин у кільцевому каналі під час руху обертової поверхні створюються різні динамічні тиски, внаслідок чого виникає неперервна циркуляція пристінного шару робочого середовища, що омиває чутливий елемент. Завдяки цьому збільшується значення коефіцієнта конвективної тепловіддачі в робочому зазорі $\delta$, що призводить до зменшення методичної похибки вимірювання. Результати проведених авторами досліджень на макетах перетворювачів показали, що щілини різної ширини й утворений ними нерівномірний кільцевий канал за лінійних швидкостей поверхні до $5 \mathrm{~m} / \mathrm{c}$ практично не створюють різниць динамічного тиску робочого середовища в зазорі і його циркуляції. Тобто застосування цього методу зменшення тепловтрат у пристінному шарі для швидкостей поверхні до $5 \mathrm{~m} / \mathrm{c} \epsilon$ малоефективним.

Тепловий екран потрібно виготовляти 3 матеріалу 3 високим коефіцієнтом теплопровідності (зазвичай мідь). Конструктивно тепловий екран становить два ребра різного радіуса, які з'єднані між собою вершинами. Чутливий елемент перетворювача встановлюється біля основи ребер теплового екрана і в одній площині 3 ним. Завдяки високій теплопровідності температура екрана повинна бути рівномірною по всьому його об'єму і близькою до температури пристінного шару середовища в робочому зазорі між перетворювачем і досліджуваною поверхнею. Дослідження, що ми провели, показали, що температура теплового екрану є близькою до температури пристінного шару робочого середовища тільки на його торчаках, а по висоті екрану від торчака до вершини рівномірно зменшується за законом теплопередачі через циліндричну стінку. Однак, порівняно 3 методом застосування неперервної циркуляції робочого середовища в зазорі, методична похибка вимірювання зменшилася майже в 2 рази. Недоліком застосування теплового екрана $\epsilon$ те, що він має порівняно велику масу і внаслідок цього значно погіршуються динамічні властивості перетворювача. Отже, тепловий екран конструктивно необхідно виконати так, щоб його маса за можливості була мінімальною. Для цього тепловий екран вимірювального блоку перетворювача запропоновано виконати у вигляді системи двох тонкостінних напівциліндричних екранів 1 і 2 різних радіусів кривизни (рис. 4), причому екраном $2 \epsilon$ захисний корпус перетворювача 3 радіусом $r_{2}$, що відповідає оптимальному значенню керуючого параметра $r$, визначеного 3 математичної моделі для деякого поєднання вхідних і збурювальних параметрів. Найбільш доцільно екрани виготовляти 3 нержавіючої сталі: екран 1 товщиною 0,2 мм і екран 2 (захисний корпус) товщиною $1 \ldots 1,5$ мм. Для уникнення можливих конвективних потоків, простір між екранами можна заповнити скловатою або іншим легким теплоізоляційним матеріалом.

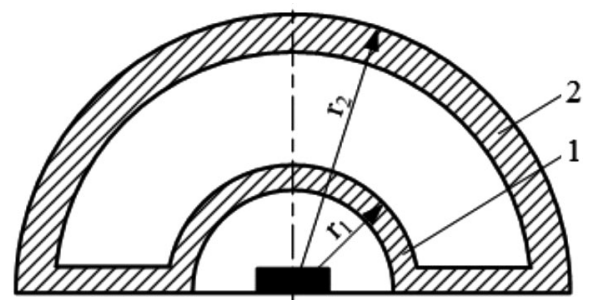

Рис. 4. Тепловий екран вимірювального блоку перетворювача

Наведені вище теоретичні основи дають змогу спроектувати вимірювальний блок перетворювача 3 мінімальним значенням методичної похибки для заданих умов експлуатації, а повна конструкція перетворювача буде формуватися залежно від специфічних умов експлуатації промислового технологічного обладнання, на якому встановлюється перетворювач.

Метрологічне забезпечення. Для забезпечення єдності вимірювань температури ОП необхідно мати методи і взірцеві засоби для метрологічної перевірки перетворювачів. Оскільки такі вимірювання належать до спеціальних вимірювань температури, то на сьогодні відсутні нормативні документи, єдина загальноприйнята методика й обладнання, а існують окремі методики для конкретних вимірювань. Однак через неточність перевірки, складності обладнання, а також відсутність 
змоги визначення впливу лінійної швидкості руху поверхні на похибку вимірювання, вони непридатні для перевірки перетворювачів для вимірювання температури обертових поверхонь.

Найбільш придатною для такої перевірки є відома установка УПТВВ-1 (Fedinetc \& Stadnyk, 1984), яка дає змогу імітувати умови, наближені до експлуатаційних, перевірюваного перетворювача, тобто робочий зазор між перетворювачем і поверхнею, лінійну швидкість і температуру поверхні, температуру навколишнього середовища. Вона $є$ циліндричним термостатом, що обертається на масивній металевій трубі. Всередині труби на нерухомому каркасі намотаний електронагрівач. Температура поверхні регулюється зміною подачі напруги на електронагрівач. Необхідна лінійна швидкість досягається зміною напруги, що подається на електродвигун, який обертає поверхню. Контрольний перетворювач опору наклеюється на рухому поверхню, а передача вимірювальної інформації до вторинного приладу здійснюється через струмознімальний пристрій, що складається із чотирьох латунних кілець і мідно-графітових щіток. Температурний діапазон установки - до $150{ }^{\circ} \mathrm{C}$, а лінійної швидкості - до 3 м/с. Основною причиною відносно невисокого температурного діапазону установки $є$ перегрівання підшипників, на яких встановлюється обертова поверхня.

За температур понад $150{ }^{\circ} \mathrm{C}$ збільшується провідність електричної ізоляції контрольного перетворювача, може відбуватися його часткове шунтування, починає проявлятися вплив тензоефекту за рахунок різних коефіцієнтів теплового розширення поверхні та наклеєного контрольного перетворювача. Внаслідок теплового розширення поверхні може зростати іії ексцентричність (биття), що ускладнить установлення перетворювача 3 фіксованим зазором.

Для збільшення температурного діапазону установки необхідно проектувати i встановлювати систему охолодження, що ускладнить їі конструкцію, зменшить експлуатаційну надійність та призведе до підвищення вартості перевірки. Але основним недоліком установки $\epsilon$ те, що контрольний перетворювач, встановлений на обертовій поверхні, немає змоги піддавати періодичній перевірці за метрологічної атестації установки і враховувати зміни похибки в процесі експлуатації. Метрологічну перевірку здійснюють залежно від температури i лінійної швидкості руху контрольної поверхні, а також від значення робочого зазору. Умови перевірки повинні відповідати умовам промислової експлуатації перетворювачів.

Зміна похибки, що зумовлена зміною лінійної швидкості досліджуваної поверхні, визначається зміною коефіцієнта конвективної тепловіддачі $\alpha$ в робочому зазоpi відповідно до (3). Розрахунки показують, що зміна методичної похибки від зміни лінійної швидкості зменшується із збільшенням температури (за рахунок зміни теплофізичних властивостей середовища в робочому зазорі) i, за лінійної швидкості 10 м/с, не перевищує $15 \%$ за температури $50{ }^{\circ} \mathrm{C}$, а за температури $300{ }^{\circ} \mathrm{C}$ не перевищує $6 \%$. Тому, з огляду на незначні зміни методичної похибки від зміни лінійної швидкості пропонуємо метрологічну перевірку проводити тільки залежно від температури досліджуваної поверхні та значення робочого зазору, а зміни методичної похибки враховувати за допомогою поправного коефіцієнта $K_{v t}$ (рис. 5), перемножуючи отримане значення похибки на $K_{v t}$.

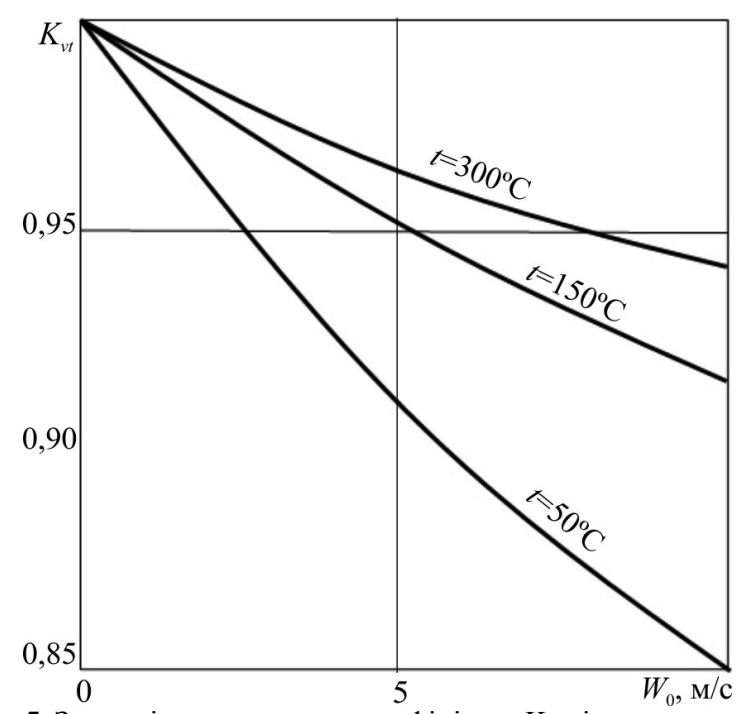

Рис. 5. Залежність поправного коефіцієнта $\mathrm{K}_{\mathrm{vt}}$ від температури $\mathrm{i}$ лінійної швидкості обертової поверхні

3 урахуванням наведеного вище, запропоновано установку для метрологічної перевірки перетворювачів із температурним діапазоном вище $200{ }^{\circ} \mathrm{C}$. Вона $\epsilon$ нерухомим напівциліндричним барабаном (рис. 6) із необхідним радіусом кривизни, на який накладається знімна контрольна поверхня 1 із встановленим на ній контрольним перетворювачем 2.

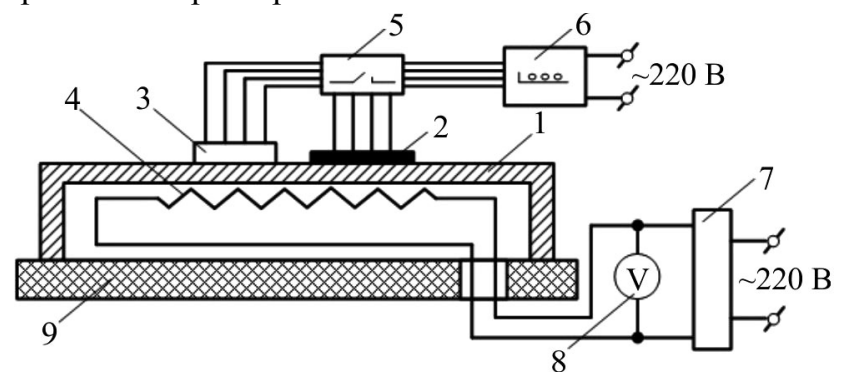

Рис. 6. Установка для метрологічної перевірки перетворювачів із температурним діапазоном вище $200^{\circ} \mathrm{C}$

Знімна поверхня виключає основний недолік існуючої установки УПТВВ-1 - неможливість перевірки за метрологічної атестації контрольного поверхневого перетворювача і цим самим врахування змін його похибки в процесі експлуатації. Як контрольний перетворювач застосовують переважно хромель/копелеву термопару, затриману на поверхні, індивідуальну статичну характеристику якої враховують внаслідок перевірки. Запропоноване обладнання, окрім метрологічної перевірки, дасть змогу проводити дослідження динамічних характеристик перетворювачів, а також інші види експериментальних досліджень.

Обговорення результатів дослідження. Проведеними дослідженнями показано, що вимірювання температури ОП є специфічним видом вимірювань, оскільки перетворювачі для таких вимірювань експлуатуються у складних умовах, піддаються багатофакторним впливам як зі сторони досліджуваної ОП, так і зі сторони навколишнього середовища. Показано, що принципові рішення для вимірювання температури ОП зводяться до безконтактного й контактного методів. На основі аналізу переваг і недоліків цих методів вибрано різновид контактного методу вимірювання температури, в якому перетворювач закріплюється нерухомо відносно ОП, але на деякій віддалі (до 2 мм) і вимірює температуру пристінного шару робочого середовища, яка має 
функціональну залежність 3 температурою ОП. Застосування цього різновиду методу дає змогу уникнути багатьох джерел похибок, що притаманні іншим методам вимірювання і відповідно підвищити точність вимірювання таких температур.

Запропоновано методику опису процесів передачі тепла як від досліджуваної ОП до перетворювача, так і від нього в навколишнє середовище, яка базується на основі законів теплопередачі. Застосування цієї методики дало змогу сформулювати основні положення для математичного опису процесів передачі тепла, що відбуваються під час вимірювання температури ОП у стаціонарному режимі.

На основі математичного опису розроблено узагальнену стаціонарну детерміновану математичну модель процесу вимірювання температури ОП, яка характеризує зв'язок між вхідними і вихідними параметрами залежно від впливу керуючих і збурювальних параметрів. Аналіз математичної моделі дав змогу визначити керуючі впливи, зміною яких можна регулювати значення методичної похибки вимірювання. Показано, що таким керуючим впливом $є$ радіус захисного корпусу перетворювача і вибір його оптимального значення дасть змогу мінімізувати значення методичної похибки вимірювання для конкретного конструктивного виконання перетворювача завдяки досягненню оптимальних значень коефіцієнтів конвективної тепловіддачі від його зовнішньої і бокових поверхонь у навколишнє середовище.

Розглянуто існуючі установки для метрологічної перевірки перетворювачів. До основних недоліків установки можна віднести те, що їхній температурний діапазон не перевищує $150{ }^{\circ} \mathrm{C}$, а лінійної швидкості - до 3 м/с. Окрім цього, контрольний перетворювач, встановлений на обертовій поверхні, не маємо змоги піддавати його періодичній перевірці за метрологічній атестації установки і враховувати зміни похибки в процесі експлуатації. На основі аналізу сучасного стану запропоновано конструкцію установки для метрологічної перевірки 3 температурним діапазоном до $300{ }^{\circ} \mathrm{C}$, яка дає змогу спростити методику перевірки і враховувати зміну похибки контрольного перетворювача, встановленого на поверхні установки, в процесі ії експлуатації.

\section{Висновки}

1. Розроблено методику математичного опису теплових процесів у системі "досліджувана обертова поверхня робочий зазор - модель перетворювача" із застосуванням інструментарію теорії теплопередачі, що дало змогу сформулювати основні положення для розроблення узагальненої математичної моделі процесу вимірювання температури ОП, яка характеризує зв'язок між вхідними і вихідними параметрами залежно від впливу керуючих i збурювальних параметрів математичного опису процесів передачі тепла, що відбуваються під час вимірювання температури ОП у стаціонарному режимі.

2. Розроблено узагальнену стаціонарну детерміновану математичну модель процесу вимірювання температури ОП, яка характеризує зв'язок між вхідними і вихідними параметрами залежно від впливу керуючих і збурювальних параметрів, що дало змогу визначити керуючі впливи, зміною яких можна регулювати значення методичної похибки вимірювання.
3. На основі аналізу розробленої математичної моделі запропоновано конструкторські рішення для зменшення теплових втрат через перетворювач і зменшення методичної похибки вимірювання.

4. Проаналізовано існуючі нормативні документи та установки для метрологічної перевірки перетворювачів і на основі їхнього аналізу запропоновано конструкцію нової установки, що дало змогу спростити і здешевити метрологічну перевірку і підвищити ії точність.

Отримані результати дають змогу створювати вимірювальні перетворювачі одного або декількох параметрів із заданими функціональними можливостями та характеристиками.

\section{Перелік використаних джерел}

Fedinetc, V. A., \& Stadnyk, B. I. (1984). Method of calibration of temperature control devices for rotating objects. Sostoianie $i$ perspektivy razvitiia sredstv izmereniia temperatury: Piataia Vsesoiuznaia nauchno-tekhnicheskaia konferentciia: tezisy dokladov, (Vol. 1), (pp. 144-145). Lvov. [In Russian].

Ilkiv, I. M., Vankevych, P. I., Spichak, V. S., \& Bohutskyi, S. M. (2013). Improvement of the design parameters of temperature control devices that reproduce the trajectory of the movement of experimental objects. Proektuvannia, vyrobnytstvo ta ekspluatatsiia avtotransportnykh zasobiv i poizdiv, 21, 37-45. [In Ukrainian].

Isachenko, V. P., Osipova, V. A., \& Sukomel, A. S. (1981). Heat transfer. Moscow: Energoizdat, 416. [In Russian].

Ivanyk, Ye. H., \& Vankevych, P. I. (2015). Modeling of thermal processes in systems of contact measurement of temperature of structural elements of military equipment. Viiskovo-tekhnichnyi zbirnyk, 13, 7-12. [In Ukrainian].

Kutateladze, S. S. (1990). Heat transfer and hydrodynamic resistance. Moscow: Energoatomizdat, 367. [In Russian].

Lebed, V. H., Myrhorod, Yu. I., \& Ukrainets, Ye. O. (2011). Aerohydro-gas dynamics: a manual. Kharkiv: Kharkivskyi universytet Povitrianykh Syl im. Ivana Kozheduba, 415. [In Ukrainian].

Lisienko, V. G., Shchelokov, Ia. M., \& Ladygichev, M. G. (2004). Rotating furnaces: heat engineering, control, ecology. Moscow: Teplotekhnik, 592. [In Russian].

Lutsyk, Ya. T., Huk, O. P., Lakh, O. I., \& Stadnyk, B. I. (2006). Temperature measurement: theory and practice. Lviv: Beskyd Bit, 560 . [In Ukrainian].

Mikheev, M. A., \& Mikheeva, I. M. (1977). Heat Transfer Basics. Moscow: Energiia, 343. [In Russian].

Petrychenko, H., \& Hots, N. (2011). Method of contactless measurement of temperature for the radiation of a metal melt in the process of electroslag remelting. Metrolohiia i prylady, 6, 25-30. [In Ukrainian].

Stepaniak, M. M., Skolskyi, V. R., \& Stepaniak, M. V. (2010). Investigation of the possibility of increasing the accuracy of measuring the temperature of rotating objects. Vymiriuvalna tekhnika ta metrolohiia, 71, 13-23. [In Ukrainian].

Vankevych, P. I. (2016). Investigation of the dynamic characteristics of parasitic signals in the systems of measuring control of moving elements of mechanized mechanical equipment. Viiskovotekhnichnyi zbirnyk, 14, 127-131. [In Ukrainian].

Vankevych, P. I. (2017). Optimization of the parameters of moving contact devices for measuring temperature with magnetic thermosensitive elements for the modernization of control-measuring systems of military-technical complexes. Systemy obrobky informatsii, 5(142), 10-14. [In Ukrainian].

Vankevych, P. I., Ivanyk, Ye. H., \& Sikora, O. V. (2017). Methods of control of the thermal condition of units and aggregate of military equipment by permanently mounted diagnostic devices. Viiskovotekhnichnyi zbirnyk, 17, 3-9. [In Ukrainian]. 


\section{ОСОБЕННОСТИ ИЗМЕРЕНИЯ ТЕМПЕРАТУРЫ ЦИЛИНДРИЧЕСКИХ ВРАЩАЮЩИХСЯ ПОВЕРХНОСТЕЙ}

Рассмотрены методы измерения температуры цилиндрических вращающихся поверхностей на основе контактного измерения температуры пристенного слоя рабочей среды омывающей вращающуюся поверхность, которая имеет функциональную зависимость с температурой поверхности. Показано, что пристенный слой рабочей среды между вращающейся поверхностью и преобразователем имеет некоторый перепад температур, являющийся основным источником возникновения методической погрешности измерения температуры вращающейся поверхности. Разработана методика математического описания тепловых процессов, происходящих во время измерения температуры цилиндрических вращающихся поверхностей и обобщена стационарная математическая модель процесса измерения температуры вращающихся поверхностей, характеризующая связь между входными, выходными, управляющими и возмущающими параметрами процессов передачи тепла во время измерения температуры вращающихся поверхностей в стационарном режиме. Анализ разработанной математической модели дал возможность уменьшить теплопотери через преобразователи и синтезировать преобразователи температуры с минимальным значением методической погрешности измерения температуры для заданных условий эксплуатации. Рассмотрены особенности метрологической проверки преобразователей температуры и предложена установка для ее проведения, что дало возможность упростить метрологическую проверку и повысить ее точность.

Ключевые слова: измерение температуры; вращающиеся цилиндрические поверхности; преобразователь температуры; тепловой поток; математическая модель; методическая погрешность; метрологическая проверка.

V. O. Fedynets, Ya. P. Yusyk, I. S. Vasylkivskyi

Lviv Polytechnic National University, Lviv, Ukraine

\section{SOME FEATURES OF MEASURING THE TEMPERATURE OF CYLINDRICAL ROTATING SURFACES}

The problem of measuring the temperature of cylindrical rotating surfaces by a kind of contact method is reviewed. In this method the transducer is fixed motionless relative to the rotating surface (RS) at a distance of up to $2 \mathrm{~mm}$ from it and measures the temperature of the wall layer of the working medium, which has a functional dependence on the surface temperature. It is shown that the wall layer of the work environment between the RS and the converter has a certain temperature difference, which is the main source of the methodical error of measuring the temperature of the RS. Therefore, there arises a need to develop methods for reducing heat losses and, accordingly, the methodological error of measurement. The method of mathematical description of heat transfer processes in the system "investigated rotating surface - working gap - converter model" using the theory of heat transfer tool is developed. On the basis of the mathematical description, a generalized stationary deterministic mathematical model of the process of temperature measurement of cylindrical rotating surfaces is developed. The analysis of the mathematical model enabled us to determine the control influences, the change of which can minimize the value of the methodological error of temperature measurement for a specific constructive implementation of the converter. The practical value of the research conducted is that the existing methods of measuring the temperature of cylindrical rotating surfaces are systematized, with the analysis of their advantages and disadvantages, and the kind of contact method that is appropriate to be used for measuring the surface temperatures of such objects is determined. By analysing a mathematical model one can develop a method for designing basic constructions of a measuring block of the converter with a minimum value of methodical measurement error. Existing installations for metrological check of converters are considered. On the basis of the analysis of the present state, the design of the installation for metrological verification with a temperature range up to $300{ }^{\circ} \mathrm{C}$ is proposed, which enables simplifying the verification procedure and considering the change in the error of the control converter installed on the installation surface during its operation.

Keywords: temperature measurement; cylindrical rotating surfaces; temperature converter; heat transfer; mathematical model; method error; metrological check. 